\title{
William Nicol - praktiese gelowige in diens van die Kerk $^{1}$
}

P J S G du Plessis

\section{ABSTRACT}

\section{William Nicol - practical believer in service of the Church}

This article focuses on William Nicol as practical believer in his own time and context. The aim is to indicate his permanent contributions to the Dutch Reformed Church of the last decades of the twentieth century. He was truly a man who lived according to the love-commandment. He endeavoured to make Jesus Lord in all walks of life. He was no great theologian, but a man of action. He represented the body of Christ, the Church, amongst his people. He served and led his people in a time of distress. He helped his people to regain their pride and to realise the importance of faith.

\section{INLEIDEND}

Dr William Nicol het jare lank 'n baie prominente rol in die Nederduits Hervormde of Gereformeerde Kerk van Suid-Afrika gespeel. Hy het die kerklike toneel in die Transvaal op alle terreine feitlik geheel en al oorheers. Hy het vanaf sy bevestiging in 1913 in Johannesburg-Oos tot sy emeritaat in 1948 in Pretoria-Oos dikwels die Ned Geref Kerk op talle terreine verteenwoordig. Hy was veertien jaar moderator van die Sinode (1934-1948) nadat hy reeds vanaf 1916 as aktuarius en quaestor synodi diens gelewer het. Hy was ook assessor van die Sinode (1928-1934). Buiten sy leiersrol in die Sinode en aktiewe betrokkenheid by die Raad van die Ned Geref Kerke, het hy jare leiding op ringsvlak en in sy twee gemeentes Johannesburg-Oos en Pretoria-Oos geneem. Op talle kerklike terreine het hy vir baie jare die Sinode se pas en koers by lidmate aangedui. Via die media en radio het hy die lidmate van die Ned Geref Kerk se denke oor die kerk en oor die werk van die kerk gevorm en geslyp. Hy was dus dié predikant wat bykans 35 jaar in die Transvaal as instrument in die hand van die Here 'n baie belangrike bydrae gelewer het.

Maar wie was die man? William Nicol is op 23 Maart 1887 op Robertson gebore. Hy was die enigste seun van 'n Skotse vader en 
Afrikaanse moeder. Ná sy skoolopleiding gaan hy na Stellenbosch en verwerf in 1906 sy BA-graad aan die Victoria Kollege. Hy is vanaf 19081910 'n student aan die Kweekskool, waarna hy in 1911 na die Vrije Universiteit (Amsterdam) en die Princeton Theologial Seminary gaan. Hy verwerf by laasgenoemde sy BD-graad in 1912. Terug in Suid-Afrika tree hy as algemene sekretaris van die Christen Studente Vereniging (September 1912-Julie 1913) op. Hy word as predikant op 8 Augustus 1913 in die Ned Herv of Geref Gemeente Johannesburg-Oos bevestig, waar hy vir 25 jaar werk. Hy word op 18 Junie 1938 in Pretoria-Oos bevestig, waar hy na 10 jaar se arbeid emeriteer. William Nicol dien daarna vanaf 1 November 1948 vir 10 jaar as Administrateur van Transvaal. Hy sterf op 21 Junie 1967.

Sy optrede en bydrae in belang van die Afrikaner in sy swaarkryjare, veral aan die Rand, is welbekend. Hy was in 'n groot mate vir Jan en Alleman die verpersoonliking van die Afrikaner se stryd om selfbehoud en selftrots te midde van 'n vreemde en vyandige Engelse stadslewe. William Nicol het egter nie bloot in sy persoonlike hoedanigheid by die stryd betrokke geraak nie, maar het die kerk as sigbare liggaam van Christus op aarde verteenwoordig. Die kerk was vir sy lidmate hulle behoud en sekuriteit, die anker waaraan hulle in krisistye kon vashou nadat alle ander sekuriteite hulle in die steek gelaat het en hulle radeloos en hulpeloos na leiding gesoek het. William Nicol het ook tydens sy bedieningsjare in gehoorsaamheid aan die opdrag van sy Verlosser ekumene en kerkeenheid in die Ned Geref Kerk nagestreef. In die eerste helfte van die twintigste eeu was die kerk in sy geheel nog nie vir gehoorsaamheid aan hierdie Bybelse opdrag ryp of ontvanklik nie. Daarom was hy dikwels die spreekwoordelike stem wat roep in die woestyn.

Hierdie artikel fokus op William Nicol (1887-1967) se optrede as praktiese gelowige en wil aandui watter bydrae hy tot die Ned Geref Kerk en die teologie in die laaste dekades van die twintigste eeu gemaak het. Sy bydrae en optrede kan alleenlik binne sy eie tyd en konteks gemeet word, want hy kan nie los van sy tydsgewrig gewaardeer en begryp word nie. Elke onderskeie tyd word deur verskillende geestelike, kulturele, politieke, maatskaplike, ekonomiese en ander faktore beheers. Hierdie faktore moet verreken word om invloede op hom te bepaal wat sy lewe en denke beïnvloed het. Indien hierdie faktore nie in aanmerking geneem word nie, sal dit wat William Nicol se kop werklik laat werk het, nooit begryp kan word nie. William Nicol was 'n produk van sy tyd, alhoewel hy in sommige opsigte sy tyd vooruit was. Hy het 'n visie vir die kerk se eenheid, ekumene en die verhouding met ander rasse gehad, wat nie in sy 
tyd altyd ontvanklik en aanvaarbaar vir die Ned Geref Kerk in die breë was nie.

\section{DIE STRYD VAN DIE AFRIKANER EN DIE KERK}

\subsection{Die Afrikaner onder die Unieregering}

Nicol se ampstermyn as predikant (1913-1948) het saam met die stryd van die Afrikaner geval. In die tydperk was die Afrikaner polities op soek na 'n plek in die son. $\mathrm{Na}$ die Tweede Vryheidsoorlog (1902) tot met die oorwinning van die Nasionale Party by die stembus (1948) moes die Afrikaner vir homself ' $n$ regmatige plek, tussen alles wat Engels was, in Suid-Afrika oop stry. Polities moes hy vir homself 'n selfstandige posisie verkry. Ekonomies het die Afrikaner geworstel om kop bo water te hou en moes alles in die stryd gewerp word om 'n gesonde ekonomie, waaruit hy ook voordeel kon put, daar te stel. Op maatskaplike terrein moes strukture daar gestel word om in die behoeftes en nood van die Afrikaner te voorsien. Kultureel het die Afrikaner hard gestry om erkenning as volk te verkry.

Op kerklike gebied kon die geestelike klimaat tot in die dertiger jare gekarakteriseer word met die benadering van ds A Murray (jnr). Hy het 'n evangelies-Calvinistiese benadering gehad en baie klem op die persoonlike geloofslewe en piëteit gelè. Daar is ook duidelike Metodistiese trekke in sy

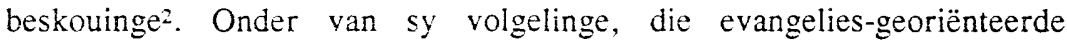
groepering (sic), "were DRC theologians who were proponents of evangelical theology and revivalist piety..." 3 . Die leraars van die Ned Geref Kerk moes hulle weerhou van party-politiek.

Apartheid as 'n "religiously justifiable ideology" 4 word na 1943 gepropageer. In dié jaar het die Raad van Ned Geref Kerke besluit dat daar Bybelse gronde vir apartheid is. Hiervolgens het 'n groot deel van die Afrikanervolk hulle as die uityerkore volk van God beskou, omdat hulle hulle met ou Israel geïdentifiseer het. Dit was heelwaarskynlik die uitvloeisel van die teologie van Abraham Kuyper. In Suid-Afrika het die neiging tot 'n pragmatiese volkskerk (NGK), voigens Ngcokovane', sterk aanklank by die "strongly Kuyperian Kulturpolitiek" van die tydperk gevind. Omdat die Afrikaner na volkseenheid gestreef het, het hulle Christelike Nasionalisme en Afrikaner-Nasionalisme as sinonieme beskou. Dit was ook die rede waarom die Ned Geref Kerk klem op in organiese verhouding tussen kerk en volk gelê het. Die kerk het 'n ai groter rol in die volkslewe, wat in "ethnically exclusive terms" gedefinieer is, gespeel. Ook Calvinisme het in die tyd by baie "n sinoniem vir rasionalisme geword. 
Wie met die leer saamstem, handhaaf die ortodokse Calvinisme, maar wie nie saamstem nie, is as liberaal bestempel. Die invloed van Duitse Nasionale Sosialisme met sy beklemtoning van rassuiwerheid op die teologie moet ook nie onderskat word nie ${ }^{6}$, sodat in Suid-Afrika 'n "exclusively Afrikaner ideology influenced by Dutch Calvinist and German ideas to explain and justify Apartheid" 7 ontstaan het.

\subsection{Die Afrikaner in die Goudstad}

In die Goudstad het die Afrikaner op geestelike gebied 'n stryd om oorlewing gehad. Die Kerk, en by name die Nederduits Hervormde of Gereformeerde Kerk van Suid-Afrika, was ten nouste by hierdie stryd betrokke. Dit was sy lidmate en sy ampsdraers se stryd. Die kerk was dié behoudende faktor wat hulle saam gebind het en aan hulle sekuriteit gebied het. Met Nicol se koms na die Goudstad in 1913 het hy noodgedwonge deel van die stryd geword, want hy het besef dat die Afrikaner, die kerk en in besonder sy Here hom nodig het om die evangelie uit te dra, maar ook om die mens in sy nood by te staan.

\section{NICOL SE BYDRAE TOT DIE KERK}

\subsection{Nicol as praktiese teoloog}

William Nicol se bydrae tot die kerk kan nie los van die gees en omstandighede van sy tyd gewaardeer word nie, want hy was deel van 'n gemeenskap. As verteenwoordiger van 'n kerk, wat ten nouste by die Afrikaner se stryd betrokke was, het hy meer as sy deel tot die stryd bygedra.

William Nicol het egter nooit om diep deurdagte teologiese redes by die stryd betrokke geraak nie, want hy het meestal slegs die teologie van sy tyd gereflekteer. Marais ${ }^{8}$ het gesê dat hy twyfel of Nicol ooit veel "teologiese" belangstelling in die enger sin van die woord gehad het, want hy was 'n praktiese Christen. Hy het as leier voortdurend na nuwe weë gesoek om die Christelike boodskap in die samelewing in te dra. Hy het 'n beperkte teoretiese belangstelling in die teologie gehad en was geen teologiese denker nie. Hy was baie intelligent, maar was nie 'n spekulatiewe denker nie. Hy was eerder 'n praktiese denker. As hy gevoel het dit is ons mense wat hulp nodig het en die kerk het die taak om hulle op te hef, het hy geen verdere teologiese fundering nodig gehad om dit te doen nie. Die liefdesgebod het dit geëis. Daarom het hy gehandel ${ }^{9}$. Dit was die 
rede waarom Nicol, aan die een kant, hom sterk vir die Afrikaner se saak kon beywer, maar aan die ander kant, hom voortdurend met die ekumeniese beweging kon vereenselwig. Dit was waarom hy hom ten gunste van enkelmediumskole kon uitspreek, maar ook vir inskakeling by die Christenraad en die Wêreldraad van Kerke kon pleit. Hy was lief vir sy eie, maar liewer vir die kerk van Jesus Christus op aarde. Hy het ook daarteen gewak om nie bloot na die volksmond te praat nie, maar het na die hart van die saak gegaan. Hy wou nie met 'n boodskap van tydelike waardes sy taak as leraar vervul nie. Hy wou uitkom by die diepste menslike behoefte om vrede met God te maak ${ }^{10}$.

Dieselfde beginsel het ook in sy betrokkenheid by die AfrikanerBroederbond, wat in historiese konteks verstaan moet word, gegeld. Hy het betrokke geraak by ' $n$ diensorganisasie wat ' $n$ reddingspoging vir die verstedelikte Afrikaner was. Byeenkomste is aanvanklik van die kansels afgekondig. Later jare, toe die beweging van rigting verander en 'n streng apartheidsbeleid gevolg het, het hy soms met die beweging verskil en het sy betrokkenheid afgeneem. Volgens Marais ${ }^{11}$ het hy het nooit die "klassieke apartheidstelsel" aanvaar nie.

Later jare het hy ook nie met radikale Afrikaners, wat die Afrikaner wou afsonder en kontak met ander groepe wou verbreek, om dieselfde vuur gesit nie, want hy was 'n brugbouer tussen Engels- en Afrikaanssprekendes. Hy het nie oor die beginsels geredeneer nie, maar vanuit die praktyk. Daarom het hy gevoel dat die nasies apart moet vergader, byvoorbeeld in die kerk en skole, omdat dit prakties was. Dit is ook waarom hy 'n voorstander van segregasie was, want hy wou bloot maatskaplike apartheid handhaaf. Hy het egter baie goed besef dat daar geen ongelykheid in die oë van die Here was nie, want die Here onderskei slegs tussen gelowiges en vyande van Christus.

Hierdie praktykgerigte benadering van hom verklaar sy betrokkenheid by die stigting van die NG Sendingkerk in Transvaal en die Federale Sendingraad. Op die wyse kon die blanke sy verantwoordelikheid en voogdyskap teenoor die anderskleuriges nakom. Hy het altyd teen uiterstes gewaak en die goue middeweg nagestreef. Vir sy kinders het hy ook eerbied teenoor anderskleuriges geleer en dit self uitgeleef. Dit verklaar ook waarom hy in die vyftigerjare vir Marais kon aanmoedig om sy Kleurkrisis en die weste. ' $n$ Studie i/s kleur en kleurverhoudings in Amerika te publiseer ${ }^{12}$, ten spyte van teenstand uit Afrikanergeledere. Nicol het selfs aan die einde van sy lewe vir Marais dankie gesé dat hy die Ned Geref Kerk "geboelie" het om teologies van apartheid af te sien. Sy vriendekring getuig ook van sy benadering ten opsigte van die anders- 
kleuriges: Thys Heyneke, 'n Smutsman, het 'n kleurlingseun aangeneem en Ben Marais, se standpunt oor apartheid is wel bekend. Nicol is dikwels beskuldig dat hy 'n verstarde Afrikaner is. Dit was nie waar nie, want hy was 'n warm persoon en 'n natuurlike ekumeniese mens, wat moeite met die verhouding tot ander Christene in ander kerke gemaak het en gevoel het dat almal in Suid-Afrika mekaar nodig het. Hy het gesê as die Afrikaner homself beter leer ken, sal hy ook met groter vrymoedigheid met ander kan skakel.

Sy seun, Willem, het gesêt ${ }^{13}$ dat hy sy pa baie sien lees het... maar nooit 'n teologiese boek nie, want hy was 'n "simple kind of practical evangelist". Tussen sy boeke was daar wel goeie kommentare en dogmatiese boeke, onder andere J H Bavinck se Magnalia Dei. Dit was vir hom belangrik om die wesenlike dinge van 'n toegewyde geloofslewe te beklemtoon. Bavinck se woorde op sy sterfbed14: "Aan mijn geleerdheid heb ik nu niets meer; mijn dogmatiek baat mij ook nu niet meer; alleen het geloof maakt mij zalig" is 'n goeie beskrywing van Nicol se benadering. Hy was 'n "helder, praktiese, eenvoudige" 15 predikant en het boeke van Andrew Murray en F B Meyer gelees, boeke wat hom gehelp het om 'n praktiese Christen te wees.

Teologies het hy aanklank by die "evangelicals" gevind. Sy liefde vir Murray en sy boeke getuig daarvan. Sy werke het hom só beïnvloed dat hy "langsamerhand geleer het om dié boeke naas die Bybel te stel"16. Volgens hom was Murray 'n "praktiese mistikus... wat nooit los van die Woord mymer nie, maar met sy gemoed vol van God's Woord... God's Gees toe(laat) om in hom te werk totdat die waarhede van die Woord vrugbaar in sy lewe word..."17. In dié opsig het Murray op hom 'n invloed uitgeoefen, want Nicol wou onder die leiding van die Heilige Gees prakties sy geloof op alle terreine uitleef. Sy lewe het soos dié van Murray sterk puriteinse trekke vertoon. Hy het sy optrede altyd aan die Woord van God getoets en was ook sy hele lewe deur by sake wat die praktiese geloofslewe raak betrokke, soos die stryd teen drank, Sabbatsontheiliging, prostitusie, dobbel en loterye. Daarom het hy ook geskryf18: "Die verkondiging van hierdie verborge lewe, wat Christus deur sy Gees in die gelowige plant en wat geopenbaar word in oorwinning en diensvaardigheid, is - na my oordeel - die nalatenskap van Andrew Murray aan ons volk en die bedrukte mensdom".

As evangeliese Christen het sy geloof hom verbind tot ' $n$ hartsverandering by homself en by ander. Hy het 'n sendinggerigte piëtisme gehad en was as sielesoeker diep geïnteresseerd in die veranderde en vernuwende werking van die evangelie in die harte van mense het. Daarom was die 
tema van sy prediking en sy persoonlike getuienis altyd die sonde en die behoefte van die mens, die liefde van God en die soenverdienste van ons Here Jesus Christus ${ }^{19}$. Buiten sy vroom lewensbenadering was daar nie veel van Murray se teologie by hom of in sy preke nie.

Nicol was evangelies betrokke by sy lidmate en 'n warm mens, maar was nooit 'n gevoelsprediker nie. Hy het nooit geskreeu nie, maar in sy prediking eerder sag en hard gepraat, want hy het 'n wonderlike beweging in sy stem gehad 20 . Hy het met 'n natuurlike stem gepraat, terwyl die meeste ander predikante nog "gebulder" het ${ }^{21}$. Dit was vir hom die grootste kompliment dat hy nie mense se emosies opgesweep het nie.

Hy het wel uitsprake gemaak wat aan 'n "mak vorm van revivalisme" herinner het ${ }^{22}$, want hy het voortdurend van herlewing gepraat. Nicol het veral Pinkstergeleenthede gesien as tye waarin die gelowige op 'n besondere wyse deur die Heilige Gees besiel en gelei kan word ${ }^{23}$. Verskeie kere het hy gesê hy sien uit na herlewing, bedoelende in die trant van die Paarlse gebeurtenisse ${ }^{2+}$ van die vorige eeu. Hy wou hê mense moet die Here prakties met hulle hele lewe begin dien.

Beweringe dat hy deur die Gereformeerde teologie van Abraham Kuyper beïnvloed is tot ' $n$ eksklusivisme vir die Afrikaner, is egter nie waar nie. Hy het wel die Gereformeerde teologie streng aangehang en verdedig. Dit is duidelik in sy stryd teen die Roomse Kerk, die Oxfordgroep en die Afrika Evangeliese Bond. Sy aanhang van die Gereformeerde leer was soos hy dit by Hodge op Princeton geleer het. Beslis nie in die lyn van Kuyper en die Gereformeerde Kerk nie. Hy het duidelik na sy oorsese studies gesê hy het nie van die tyd in Amsterdam gehou nie. Sy seun, Willem, onthou goed dat hy gesê het wanneer mense begin redeneer en sê dis dié of daardie beginsel het dit hom koud gelaat ${ }^{25}$ en dat hy só 'n persoon nie vertrou nie. Hy was dus predikant in 'n breë Gereformeerde tradisie met 'n evangeliese hart ${ }^{26}$. Sy kerk-, skrif- en godsbeskouing het nie wesenlik afgewyk van die Gereformeerde beskouinge van sy tyd nie.

Nicol se bydrae as leraar moet nie op die terrein van die teologie gesoek word nie. Dit moet liewer op die terrein van die kerk se taak in die wêreld gesoek word. Hier het hy Christus en sy liefdesboodskap op alle terreine verteenwoordig en op 'n Skrifgehoorsame en -getroue wyse uitgelewe. Hy het prakties gewys dat die gelowige nie wêreldvreemd moet wees nie, maar Christus se antwoorde aan die wêreld moet bied. 


\subsection{Nicol se bydrae tot die Ned Geref Kerk}

Nicol sal in die Ned Geref Kerk seker die beste onthou word as 'n uitstaande kerkleier, wat in sy tyd 'n legende as voorsitter van vergaderings geword het. Sy bydrae tot die totstandkoming van die administrasie en organisasie van die kerk, die Teologiese en Mediese Fakulteite aan die Universiteit van Pretoria en tot kerklike tydskrifte is onvergeetlik. Hy het waagmoed aan die dag gelê en die kerk se boodskap via moderne kommunikasiemiddele die wêreld ingedra, maar die kerk was nog nie vir sy pogings tot kerklike eenheid óf vir sy ekumeniese strewe gereed nie.

Die kerkkantoor en die sinodale sentrum in Pretoria is stille bewyse van sy versiendheid ten opsigte van die kerk se administrasie. Toe hy in 1916 as aktuarius verkies en later as quaestor synodi aangestel is, was daar geen amptelike kerklike administrasie of finansiële beheer nie. Omdat hy die organisasie van die kerk as sy stokperdjie beskryf het, het hy baie tyd bestee om die leemte reg te stel. Dalk te veel tyd... Hy skryf ${ }^{27}$ : “(Ek) hou... my leë dekades hiermee aan jonger predikante van ons kerk voor as 'n skrikwekkende voorbeeld van hoe die aksent in ons diens kan val as ons nie waak nie". Vanweë sy ywer het die Nederduits Hervormde of Gereformeerde Kerk in $1925 \mathrm{mnr}$ Sydney Martin as saakgelastigde aangestel om die kerk se sake te behartig en is die Voortrekker-Gedenksaal gebou as kantoorruimte en vergaderplek van die kerk. Hy was ook dié leraar wat hom daarvoor beywer het dat leraars by die pensioenfonds moes aansluit om vir hulle aftrede voorsiening te maak.

Hy het veral as voorsitter, tydens sy veertienjaarlange termyn as moderator, baie gedoen om die Sinode se vergaderingsprosedures te skaaf en die lang omslagtige sittings te verkort en vaartbelyn te maak. Sy humorsin, skerp brein en logiese, praktiese manier van dink en doen, het hom gehelp om dit op so wyse te doen dat dit almal tevrede gestel het. Hy het ook die besondere gawe gehad om die ingewikkeldste dinge tot die eenvoudigste terme te reduseer en aan die einde van 'n lang en verwarde bespreking die paar belangrike dinge op so 'n manier na vore te bring dat almal dit kon verstaan. Dit is dan ook hier waar die kragpunt van Nicol as voorsitter en leier van mense gesoek moet word ${ }^{28}$. As moderator moes hy dikwels die noodsaaklikheid van 'n Teologiese Fakulteit te Pretoria motiveer. Nadat die fakulteit tot stand gekom het, was hy lewenslank by dié belangrike kerklike opleidingsentrum betrokke. Namens die kerk was hy ook by die totstandkoming van die Mediese Fakulteit en koshuise betrokke. 
Hy het besef hoe belangrik die media vir die verspreiding van die evangelie was en huiwer nie om die pers vir advertensies van die kerk en dienste te gebruik nie. Hy was die eerste leraar in Transvaal wat in 1925 'n direkte diens in Afrikaans uitgesaai het. Daarna gebruik hy die radio gereeld vir godsdienstige uitsendings en deur sy betrokkenheid word al meer tyd aan godsdienstige uitsendings afgestaan. Sy joernalistieke gawes het hy gebruik om in Die Kerkbode en Die Voorligter die evangelie en kerknuus onder die lidmate se aandag te bring. Hy het die evangelie nie net in kerklike tydskrifte gebring nie, maar ook in Afrikaanse en Engelse koerante en tydskrifte. Hy versprei ook die evangelie deur 'n Klankbybel op plaat onder kinders en leer die kinders kerkgeskiedenis deur middel van tekenverhale.

Die eenheid van die kerk was vir hom belangrik. Daarom wend hy talle pogings in die twintiger- en veertigerjare by die Raad van Kerke aan om die Ned Geref Kerk se kerkverband, wat met die Loedolffsaak verbreek is, te herstel. Sy pogings was elke slag vrugteloos, veral nadat hy in 1947 via die media en ander kanale die saak bevorder het. Hy het egter deur sy pogings die proses aan die gang gehou en kon in 1962 die vreugde van die verenigde Ned Geref Kerk, as ouderling, smaak. Hy was ook ten nouste betrokke by pogings van die Raad van Kerke om die drie Afrikaanse kerke nouer te laat saamwerk, al was daar van tyd tot tyd wrywing tussen hom en die Nederduits Hervormde Kerk. Sy ywer vir samewerking word ryklik beloon toe die Tussenkerklike of Interkerklike Kommissie, waarvan hy die eerste voorsitter was, die eerste keer in 1939 vergader. (Die Hervormde Kerk het nie saam vergader nie, maar wel in 1943 by die Tussenkerklike Kommissie aangesluit).

Die kerk in breër verband was vir hom belangrik. Reeds as student op Princeton doen hy moeite om met studente van oraloor te skakel. In Suid-Afrika was hy betrokke by die Witwatersrand Church Council, maar sy betrokkenheid by die totstandkoming van die Christenraad is seker die beste voorbeeld. Hy was die eerste voorsitter, wat getuig van die ander kerke, ook Engelse kerke, se vertroue in hom en sy vermoëns. Die Engelse wêreld se onvermoë om Afrikaans, wat vir hom belangrik was, te erken en die stroom in die Nederduits Gereformeerde Kerk, wat nie met ander kerke wou skakel nie, maar in hulle eie eksklusivisme wou opgaan, noodsaak hom om te onttrek. 'n Ander voorbeeld was sy betrokkenheid by die Sunday School Association se konferensie wat hy moes reël. Weer eens was sy eie kerk se benadering en sendingbeleid vir hom 'n struikelblok. Die kerk was so vasgegryp in die greep van sy sendingbeleid, wat samewerking met ander kerk-, taal- en rassegroepe vermy het, dat al sy 
pogings tot ekumeniese samewerking vir hom tot groot hartseer gelei en teleurstellend geëindig het.

Hy het ook prakties aan die behoeftes van die anderskleurige lidmate van die Ned Geref Kerk probeer dink. Hy wou hulle as mede-gelowiges in Christus probeer akkommodeer. Dit was nie aldag baie maklik nie, want die optrede van die kerk het tot 'n al groter wordende verwydering tussen gelowiges in verskillende kerke in Suid-Afrika gelei. Daarom het hy die voorstel vir die stigting van die afsonderlike NG Sendingkerk in Transvaal ingedien en was hy ten nouste by die stigting van die Federale Sendingraad betrokke. Hy het geglo dat dit prakties baie beter vir die anderskleuriges is om op hulle eie te vergader, maar sy ekumeniese hart beweeg hom om 'n Federale Sendingraad voor te stel. Op dié wyse kon kontak met die anderskleuriges behou word. Hy wou hê dit moes die Ned Geref Kerk se eie Christenraad wees. Dit het egter na sy aftrede nie so gerealiseer nie, want talle het die Sendingraad as instrument in die realisering van die apartheidsbeleid gesien. Hy het as praktiese mens nie 'n Skriftuurlike fundering vir apartheid gesoek nie, maar bloot geglo dit is die beste manier van doen. Op dié wyse wou hy 'n toekoms vir sy kerk, maar ook vir die Afrikanervolk, bewerkstellig.

Hy het altyd gepoog om polities neutraal in sy optrede te wees, al is hy dikwels beskuldig dat hy of die Smutsregering aan die een kant óf die Malanbeweging aan die ander kant steun. Hy bewys egter die teendeel deur die Evangelie aan almal in die kerk en land te verkondig. ' $n$ Voorbeeld is sy besoek aan die Midde-Ooste tydens die Tweede Wêreldoorlog en die gevolglike verspreiding van 'n groot aantal Bybels aan die manne in uniform. Hy was ook midde in die pogings om veldpredikers vir die soldate te kry. Die Afrikaners aan die ander kant van die politieke spektrum kon ook op die kerk en sy hulp staat maak, want hy het hulle in interneringskampe besoek en wend selfs pogings aan om te verhoed dat predikante geïnterneer word. Tydens 'n vergadering, wat hy met predikante gereël het, wys hy hulle op hulle primêre taak en poog om die geweldige skeuring in die Afrikaner- en kerklike geledere te ondervang. Hy het egter gemengde welslae behaal.

Nicol het met sy praktiese benadering probleme in die beroepstelsel raakgesien en beveel 'n pre-advieskommissie by gemeentes aan. Hy wou selfs hê dat ringe ook name aan dié kommissie moes kon deurgee. Met dié insigte en aanbevelings was hy die kerk ligjare vooruit, want die saak wat hy aangeroer het, word eers by die Algemene Sinode van 1990 goedgekeur. 
Nicol was as sielesoeker baie bekommerd oor die onverskilligheid van lidmate in wie se daaglikse lewens hulle kindskap van die Here nie raakgesien kon word nie. Daarom was hy by die stryd teen talle openbare euwels, byvoorbeeld drank aan gekleurde mense en die dopstelsel, honderesies, dobbelary en staatsloterye en Sabbatsheiliging betrokke. Hy wou deur sy betrokkenheid lidmate, maar veral die eer van sy Here, beskerm. Hierdie praktiese benadering tot die lewe het hy as administrateur ook voortgesit. Sy bekommernis oor mense se verhouding met die Here dra by tot sy betrokkenheid by die sending. Daarom was hy altyd betrokke by die uitdra van die evangelie na die Jood, die nie-blanke in sy kampong of in die hospitaal of in sy woonbuurt... maar die evangelie moes versprei en uitgeleef word.

Hy sien die geestelike agteruitgang by talle lidmate en was al in 1945 baie bekommerd oor die geestelike toestand van die komende geslagte. Om dié rede was hy ook oor die kerk se toekoms begaan en wonder of die kerk na die einde van die eeu sal groei. Die antwoord lê volgens hom in die belangrikheid van evangelisasie. Dit sal bepaal of "ons kinders teen 1975 aan... hierdie eeu as die mees-geseënde sal dink" 29 . Die kerk moet aanpas by die stad en sy nuwe eise en daar moet onthou word die "Christen se stryd is nie in die eerste plek teen ander rasse nie, maar teen ongeloof, onsedelikheid, onkerksheid en al die ander moderne euwels" 30. In 1965 beklemtoon hy weer die noodsaaklikheid van evangelisasie onder kerkvervreemdes en sêt ${ }^{31}$ die kerk moet bid en werk vir herlewing wat sal bestaan in die verdieping van die geestelike lewe in Christus en die terugbring van afvalliges. Hy het die gevare betyds aan die kerk, wat net daarvan kennis geneem het, uitgewys. Geen wonder dat sy vrese bewaarheid is nie.

\subsection{Nicol se bydrae tot die gemeentelike lewe}

Op gemeentelike vlak sal Nicol seker onthou en gewaardeer word vir sy betrokkenheid by die nood van sy lidmate. Toe Johannesburg-Oos op 'n stadium 'n nuwe kerkgebou noordwaarts wou oprig, het hy vasgeskop en gesê die kerk moet in die stad bly, want dit is waar sy lidmate en die nood is. Nicol kan dus met reg beskou word as die leraar wat ook die belangrikheid van die kerk se bediening in die middestad besef het.

$\mathrm{Hy}$ het ook in die gemeentes aandag aan die administrasie gegee. Dit is opvallend dat in albei die gemeentes waarin hy gearbei het, naamlik Johannesburg-Oos en Pretoria-Oos, 'n saakgelastigde deur sy toedoen aangestel is. In Pretoria-Oos het hy die saak vir 'n Kommissie vir 
Algemene Doeleindes, waar lidmate met die spoedige afhandeling van talle sake help, bepleit.

Sy betrokkenheid by lidmate in nood blyk veral uit sy bemoeienis met die 1922-staking. Van sy lidmate was in die gebeure betrokke en hy het aan hulle hulp verleen en voedsel verskaf. Hy was selfs bereid om 'n tyd lank die salaris van 'n maatskaplike werker uit sy eie sak te dra. Omdat hy die nood besef het, pleit hy vir 'n Christelike organisasie vir die arbeiders en was betrokke by die stigting van 'n organisasie wat die arbeider se belange op die hart kon dra. Tydens die Tweede Wêreldoorlog probeer hy eensgesindheid en vrede tussen lidmate bewaar, want die Afrikaners was verdeeld oor die betrokkenheid by die oorlog. Talle lidmate het getuig van sy besondere aandag wat hy aan siek en bejaarde lidmate betoon het. Die Irenenuus en Die Ooskerk was gemeenteblaaie waarmee hy die lidmate in hulle besondere situasie wou begelei op hulle geloofspad. Sy besondere moeite met huisbesoek, wat hy rondom mense se persoonlike verhouding met Jesus Christus ingeklee het, is gewaardeer.

Hy was nie bang om nuwe dinge in die gemeente aan te pak nie. Die gebruik van die nagmaalbekertjies (kelkies) in die plek van die beker tydens die 1918-griep getuig van. sy praktiese benadering tot die sakramente. Daar was verder die Vrywillige Weeklikse Offer, waarvolgens lidmate weekliks hulle dankoffers kerk toe moes bring. Nicol wou lidmate leer om volgens die Bybelse metode hulle dankbaarheid aan die Here te bewys.

Die waarde van die huwelik en die gesin was hoog op sy prioriteitslys. Hy mak groot moeite met die voorbereiding vir die huwelik en het ouerpare voortdurend begelei om hulle kinders in die weë van die Here groot te maak. Die kerk se betrokkenheid by hulle geestelike opvoeding was vir hom baie belangrik. Hy het altyd bemoeienis met die Sondagskool gemak en alles in sy vermoë gedoen om te verseker dat jongmense wat belydenis van geloof aflê, waarlik die Here ken.

Sy preke was op die man af, met duidelike en treffende hoofpunte en 'n duidelike tema. Hy het gebruik gemaak van skrifverklaring en praktiese toepassing en dit op so 'n ordelike manier aangebied dat dit maklik was om te volg. Dit het ook van sy betrokkenheid in die kerk en die Afrikaner se stryd getuig. In die lees van sy preke kan die geskiedenis van die eerste helfte van die eeu nagespoor word, byvoorbeeld die Eerste Wêreldoorlog, politieke woelinge, die Tweede Wêreldoorlog, verkiesings, ensovoorts ${ }^{32}$. Sy aktuele prediking was egter altyd Christosentries met die klem op Christus se godheid. Hy het lidmate met Jesus Christus gekonfronteer, op hulle sonde gewys, opgeroep tot bekering en gewys op Jesus Christus as 
die Middelaar en Verlosser. Sy prediking het ook mense voortdurend aangespoor om God se onbeperkte genade op te soek. Die mens moet net roep, want $\mathrm{Hy}$ hoor en is getrou. Hy het nie gehuiwer om sondes soos drankmisbruik, dobbelary en sedelike onreinheid by die naam aan te spreek nie. Talle reekse is oor heiligmaking gehou en hy het groot klem op die liefde en genade van God gelê. Hy het aan die Ou- en Nuwe Testament ewe veel aandag gegee, maar het 'n voorliefde vir die Johannes-Evangelie gehad. Esterhuizen ${ }^{33}$ is van mening dat sy taal eenvoudig, fyn, beskaafd en goed versorg was. Sy sinne was nooit lank nie. Sy preke was sinryk, eenvoudig, dog boeiend. Nicol was ook baie lief om van illustrasies, wat sy preke vir volwassene en kind aantreklik gemaak het, in sy prediking gebruik te maak. Opvallend is die feit dat min van sy preke volledig uitgeskryf was. Die belangrike saak is egter dat die gemeente altyd deur sy preke gestig en aangespreek is. Hy het die waarde van gebed besef en in sy gemeentes die bidure altyd interessant probeer mak. Sy seun, Willem, vertel $^{34}$ dat hy nooit van lang gebede, waarin mense vir die Here probeer vertel het hoe Hy dinge moes doen, gehou het nie.

Dit is uit gemeenteblaaie en kerkraadsnotules duidelik dat Nicol 'n onuitwisbare nalatenskap vir die gelowiges van Johannesburg-Oos en Pretoria-Oos nagelaat het. Die Ooskerk" ${ }^{35}$ het dit so beskryf: "Sy teenwoordigheid in 'n erediens, op 'n kerkraadsvergadering, of sommer net in 'n subkommissie of biduur het immer 'n seënende stempel afgedruk. Sy verrassende oplossings in netelige situasies, sy humorsin en kwinkslae, sy mensekennis, sy verbasende geheue, dit alles sal lank in ons herinnering voortleef". Sy prediking was "altyd sprankelend en oorspronklik, maar ook skrifgetrou en diep ernstig...".

\subsection{Nicol se bydrae in belang van die Afrikanersaak}

Nicol was as leraar ten nouste by die wel en weë van sy volk betrokke, want die kerk was daardie dae ten nouste betrokke by die Afrikanerstryd. Die Afrikanervolk sal seker nooit vergeet wat hy gedoen het om 'n selftrots by die Afrikaner wakker te maak nie. Hy het die Afrikaner weer ' $n$ trots in sy eie volk, sy eie kultuur, sy eie taal en sy eie kerk gegee. Hy het die Afrikaner daarop gewys dat die Here hom in sy Koninkryk wil gebruik en dat jy alleen as gelowige ook ware Afrikaner kan wees.

Met sy koms na die Goudstad was die Afrikaner mismoedig en verstrooi. Daarom het Nicol nie geskroom om lid van die Afrikaner Broederbond in 1918 te word nie, want dié beweging wou die Afrikaner deur ' $n$ band van samehorigheid verenig en weer 'n trots gee. Daar moet 
onthou word dat dit die jare van die Eerste Wêreldoorlog en die Rebellie was. Die Afrikaner was diep verdeeld deur die gebeure. Later jare het Nicol duidelik van die Broederbond se koers verskil, want hy het gevoel dat Engelssprekendes en anderskleuriges saam met die Afrikaner 'n gedeelde verantwoordelikheid in Suid-Afrika het. Daarom stel hy en 68 ander Suid-Afrikaners in 1961 'n Credo op waarin hulle hul beywer om "die onderlinge verhoudings tussen die verskillende groepe van ons bevolking, binne die raamwerk van 'n beskaafde, bestendige, welgeordende en vooruitstrewende gemeenskap te bevorder"36. Die besef beweeg hom om 'n nuwe gelofte vir die inwoners van Suid-Afrika op te stel. Die hoofinhoud van die Gelofte was dat indien die Almagtige God die blanke Suid-Afrikaanse volk van dreigende gevare red, hulle toelaat om hul plek tussen die beskaafde nasies te behou en 'n eie volk op te bou sal hulle 'n daad van toewyding aan God maak ${ }^{37}$. Hy het dit egter nooit laat aflê nie. Uit die Credo blyk sy openheid teenoor die Engelssprekende duidelik. Hy het voorsiening vir noue toekomstige samewerking gemaak. Dit blyk ook duidelik dat hy, ten spyte van sy openheid op persoonlike vlak teenoor die anderskleurige, steeds aan hulle in die apartheidstrukture van sy tyd gedink het.

In sy strewe om eenheid onder die Afrikaner te bevorder het hy dikwels op tone getrap en is hy verkeerd verstaan en geïnterpreteer. Veral die pers het hom dikwels fel gekritiseer oor uitsprake waarin hy huwelike en onderwys oor kultuurgrense heen afgekeur het. Nicol wou nooit in die uitsprake anti-ander groepe wees nie. Hy wou net beklemtoon dat hy proAfrikaans, pro sy eie is. Met sy praktiese benadering en eie agtergrond het hy besef watter geweldige aanpassing en eise aan huwelike en skole waarin daar kultuurverskille is, gestel word. Hy het dikwels verklaar dat hy respek en waardering vir die ander groepe het, want almal in Suid-Afrika het mekaar nodig. Die beginsel het hy duidelik as Administrateur ook toegepas.

In sy strewe om die Afrikaner op te hef, was hy betrokke by die stigting van die Afrikaanse Kunsvereniging, die Randse Afrikaanse Kultuurvereniging, die Federasie van Afrikaanse Kultuurvereniginge, die Suid-Afrikaanse Akademie vir Taal, Lettere en Kuns, die Sentrale Volksmonumentekomitee en talle ander liggame. Al hierdie bewegings het die een gemeenskaplike doel gehad - die verkryging van 'n eie selfstandige plek vir die Afrikaner waarop hy trots kon wees. In hierdie doel het hy geslaag en 'n trotse Afrikaner nagelaat.

Die Afrikaner kon bogenoemde ideale alleen deur 'n goeie opvoeding bereik. Omdat alles tot ongeveer 1920 deur Engels as medium 
bereik is, het Nicol besef dat daar 'n geslag vir die Afrikanervolk verlore gegaan het. Hy het dus alles in die stryd gewerp om moedertaalonderrig vir Afrikaanse kinders daar te stel. Dit begin met sy betrokkenheid en organisering vir 'n verkiesing van 'n skoolkomitee in 1918. Die sukses van die verkiesing spoor hom en ander aan om ook te verseker dat die Afrikaner op die Witwatersrand-Sentraal-skoolraad verteenwoordig sal word: 'n Raad waarin hy tot 1938 dien. Sy ywer vir 'n Afrikaanse hoërskool maak dat sommige hom die vader van die Helpmekaar Hoërskool, wat in 1921 open, noem. Hy was ook ten nouste by die stryd vir enkelmediumskole betrokke, want hy het geglo dat die Afrikanerkind in sy eie skool in sy eie taal onderrig moet word. Die kind moes ook geleentheid kry om godsdiensonderrig te ontvang. Dit is tog ook waarom die kerk by die stryd betrokke was.

Sy belangrikste bydrae tot die onderwys was sekerlik sy betrokkenheid by twee provinsiale kommissies. In 1925 was hy die voorsitter van 'n kommissie wat ondersoek na beurse vir minder bevoorregte kinders moes instel. Sy uitstaande bydrae was as voorsitter van die Provinsiale Kommissie se ondersoek na Onderwys wat vanaf 1938-1939 geduur het. Die verslag het die basis vir onderwys in Transvaal gelê en talle aanbevelings is later in sy ampstermyn as Administrateur geïmplementeer. Sy kennis en praktiese betrokkenheid by die onderwys het daartoe gelei dat hy in die rade van die Universiteit van die Witwatersrand, die Universiteit van Suid-Afrika en die Universiteit van Pretoria gedien het. Die rektorspos van die Universiteit van die Oranje-Vrystaat is selfs by twee geleenthede aan hom aangebied en hy was genomineer vir dié pos by die Universiteit van Pretoria. Die vrug van sy bydrae op die terrein van die onderwys het die Afrikanerkind vir sy volk en kerk behou.

Die Afrikaner het in die eerste vier dekades van hierdie eeu baie swaar gekry en was verarm. Ekonomies het hulle gesukkel en was voortdurend verplig om ander in die oë te kyk. Die Carnegie-verslag in die dertigerjare het die armblankevraagstuk baie duidelik uitgewys. Die kerk het besef dat daar aan dié saak aandag gegee moet word. Daarom het die Raad van Kerke in 1934 'n kongres oor die armblankevraagstuk onder Nicol se voorsitterskap in Kimberley gereël. Die kongres bewerk 'n keerpunt in die armblankevraagstuk. Nicol se bydrae in hierdie poging moet nie gering geskat word nie, want die Departement van Volkswelsyn en die Christelike Maatskaplike Rade wat hieruit voortvloei, het reusewerk gedoen om die Afrikaner op te hef. Sy leiding as voorsitter by die Ekonomiese Kongres van 1939 het daartoe gelei dat die Afrikaner 'n grootse poging aangewend het om sy ekonomiese toekoms te verseker. Die 
Reddingsdaadbond wat ekonomies soveel vir die Afrikaner gedoen het, vloei ook hieruit voort. Onder sy voorsitterskap word daar in 1947 by 'n kongres oor die stedelike Afrikaner besin. Die kerk het hier by hernuwing ook kennis geneem van die feit dat die kerk en die Afrikaner 'n goddelike roeping in die stad het. Hy het 'n reusebydrae gelewer om die Afrikaner ekonomies op die been te kry.

Die maatskaplike terrein is nie deur hom verwaarloos nie. Soos vroeër in die hoofstuk vermeld, was hy na die Carnegie-verslag voorsitter van die kongres oor die Armblanke-vraagstuk en op gemeentelike vlak betrokke tydens die 1918-griep en die 1922-staking. Hy het ook deur middel van die Rand Aid Association hulp verleen. Omdat hy besorg was oor die Afrikaner in die agterbuurte het hy ten nouste met maatskaplike werkers saamgewerk om hierdie probleem aan te spreek. Sy betrokkenheid as president van die Suid-Afrikaanse Matigheidsalliansie en die betrokkenheid by maatskaplike probleme. Later jare ondersteun hy die VVO se Kinderfonds en was hy betrokke by die Nasionale Raad van Huweliksvoorligting en die Transvaalse Hartstigting.

\section{SAMEVATTEND}

Uit dit alles blyk duidelik dat Nicol 'n geweldige dinamiese figuur, 'n magtige en energieke denkkrag, 'n opregte Christen en ' $n$ innige mens met 'n kleurryke taal, diepe eenvoud en egte menslikheid was ${ }^{38}$. William Nicol was inderdaad 'n praktiese gelowige, 'n man met 'n groot sending- en ekumeniese hart, wat op die wyse 'n reusebydrae tot die lewe van sy kerk en volk gemaak het. Marais ${ }^{39}$ het met reg sy bydrae soos volg saamgevat: "As iemand nou uit dit alles opmaak dat dr Nicol eerstens kultuurleier of volksman in die breër sin van die woord was, sal hy dit tog verkeerd hê. Hy was 'n uiters begaafde mens wat veel kon doen en dit goed kon doen, maar ons wat hom intiem geken het, stem almal saam dat sy eerste liefde en belangstelling steeds die evangelie en die kerk was. Hy was 'n evangeliese Christen wie se geloof steeds verbind was met die hartsverandering by homself en by ander. Hy was geen 'formele' teoloog nie, maar dwarsdeur sy lewe 'n sielesoeker wat diep geïnteresseerd was in die veranderde en vernuwende werking van die evangelie in die harte van mense. Die tema van sy prediking en van sy persoonlike getuienis was steeds die sonde en behoefte van die mens, die liefde van God en die soenverdienste van ons Here Jesus Christus. Al het hy skynbaar met albei voete in hierdie wêreld en hierdie lewe gestaan, was hy hom steeds in alles helder bewus van die ewigheid. Hy was nooit 'n mens van één dimensie 
nie, maar iemand vir wie die ewigheid baie werklik was en wat met groot vrymoedigheid daaroor kon praat. So het hy ook gedink en gepraat oor die dood. Dit was vir hom nie die einde nie, maar 'n rusplek op pad na die Vaderhuis in die Vaderland...".

\section{NOTAS:}

1 Samevatting van 'n DD-proefskrif getiteld William Nicol (1887-1967) as Kerkman wat in 1993 ingedien is onder promotorskap van prof J W Hofmeyr, Departement Kerkgeskiedenis, Fakulteit Teologie (Afdeling B), Universiteit van Pretoria.

2 C F C Coetzee, Die werk van die Heilige Gees in die teologiese denke van Andrew Murray, Potchefstroom 1986, 227.

3 C Ngcokovane, Demons of apartheid: A moral and ethical analysis of the N.G.K., N.P. and Broederbond's justification of apartheid, Braamfontein 1989, 5.

4 D J Bosch, "The roots and fruits of Afrikaner civil religion" in: New faces of Africa (J W Hofmeyr \& W S Vorster [reds]), Pretoria 1984, 14.

$5 \quad$ Ngcokovane, $a w, 5$.

6 J A Loubser, The apartheid Bible: A critical review of racial theology in South Africa, Kaapstad 1987, 50.

$7 \quad$ Ngcokovane, $a w, 9$.

8 B J Marais, "Predikant in die stoel van Oom Paul", Huisgenoot (22 Julie 1949), 17.

9 W Nicol (jnr), Onderhoud met P J S G du Plessis, 26 September 1991.

10 Vaderland, (26 September 1941).

11 B J Marais, Onderhoud met P J S G du Plessis, 2 September 1991.

12 Onderhoud met Marais.

13 Onderhoud met Nicol (jnr).

14 GE Meuleman, "Bavinck" in: Christelijke Encyclopedie, ${ }^{21956,} 490$.

15 Onderhoud met Nicol (jnr). 
16 Private versameling van W Nicol (jnr). Radiopraatjie gehou op 4 Junie 1945: Die boeke wat my die meeste beinvloed het, is die werke van dr Andrew Murray.

17 Private versameling, W Nicol (jnr).

18 W Nicol, "Andrew Murray: Bergtop in ons menselandskap", Fleur (Desember 1946), 53.

19 B J Marais, "So ryk was sy lewe - 'n Huldeblyk aan dr William Nicol", Kerkbode (16 Augustus 1967), 227.

$20 \quad$ Marais, $a w, 1991$.

21 H Bierman, Sondagaand tuis. Uit hierdie rots: dr William Nicol, 12 November, 1978.

22 Onderhoud met Nicol (jnr).

23 Argief, Ned Geref Kerk van Transvaal (A3396bQ2). Kerkraadsnotule van NH of G Kerk Johannesburg-Oos, (12 Mei 1915), 57.

24 Onderhoud met Nicol (jnr).

25 Onderhoud met Nicol (jnr).

26 Marais, $a w, 1991$.

27 W Nicol, Met toga en troffel. Die lewe van 'n stadspredikant, Pretoria 1958, 297-298.

28 Marais, $a w, 1949,17$.

29 W Nicol, “Sal ons kerk nog groei?”, Voorligter (September 1945), 30.

30 W Nicol, "Die taak van die kerk in die stad", Voorligter (Augustus 1947), 29.

31 W Nicol. "Op pad na die jaar 2000” Voorligter (November 1965), 55.

32 E L Esterhuizen, Die lewe en prediking van dr Wm Nicol (BD-skripsie), Universiteit van Pretoria 1968, 58-59.

33 Esterhuizen, $a w, 58$.

34 Onderhoud met Nicol (jnr).

35 Die Ooskerk, (Julie 1967), 1-2. 
36 Wm Nicol-versameling, H F Verwoerd-biblioteek, Randse Afrikaanse Universiteit (A21/14.7.f.3). Kerkaangeleenthede - Credo net ná Republiekwording 1961.

37 Vaderland se Sondagblad, (17 Desember 1961).

38 Spore, (Julie-Augustus 1967), 20.

39 Marais, $a w, 1967,227$. 